Igennem en række møder med politiske aktivister fra opblomstrende venstrefløjsbevægelser i Tyrkiet undersøger denne artikel en ny form for liberal venstrefløjstænkning, som har fået liv med Geziprotesterne i sommeren 2013.

\title{
Tyrkiets nye venstrefløj
}

Af Mathias Findalen Bickersteth, cand. mag i historie og mellemøststudier fra København og Roskilde universitet.

GEZI-PROTESTERNE I SOMMEREN 2013 TOG FOR alvor fart, da en række miljøaktivister protesterede over, at regeringen ville fælde træer i Gezi-parken beliggende i Istanbuls centrum til fordel for et stort indkøbscenter. Dette udviklede sig efterfølgende til et omfattende politisk opgør mod partiet AKPs (Adalet ve Kalkınma Partisi, Retferdighed- og udviklingspartiet) autoritære regeringsførelse. En regering som med premierminister og præsident fra august 2014 Recep Tayyip Erdogans stigende raseriudbrud mod alt fra kyssende par i metroer til øldrikkende studerende i Istanbuls gader inden for få år især har fået dele af den yngre generation mod sig.

Men for mange politiske aktivister der deltog i Gezi-protesterne symboliserede protesterne ikke bare et tilfældigt raseriudbrud. Protesterne symboliserede snarere et opråb til eksisterende politiske partier, bevægelser og foreninger at genopfinde nye ideologiske platforme for at imødekomme kravene for under-repræsenterede grupper i det tyrkiske samfund. Bemærkelsesværdigt under protesterne var tilstedeværelsen af flere bevægelser, der ofte identificerer sig med venstrefløjen; feminister, LGBT-aktivister, miljøaktivister, muslimske anti-kapitalister og socialister. Gezi-protesterne blev ligeledes første gang i den tyrkiske republiks mere end 90-årige historie, hvor medlemmer fra alle positioner på venstrefløjen mødtes for sammen at mobilisere en opposition. ${ }^{1}$ Netop dette møde mellem forskellige ideologiretninger på venstrefløjen vil jeg bruge til at argumentere for, at en række nye ideologiske formationer med inspiration fra den liberale ideologi og identitet er bragt til live i Tyrkiet. Her især med fokus på relationen til rettighedsbaserede begreber som frihed, pluralisme, tolerance og 


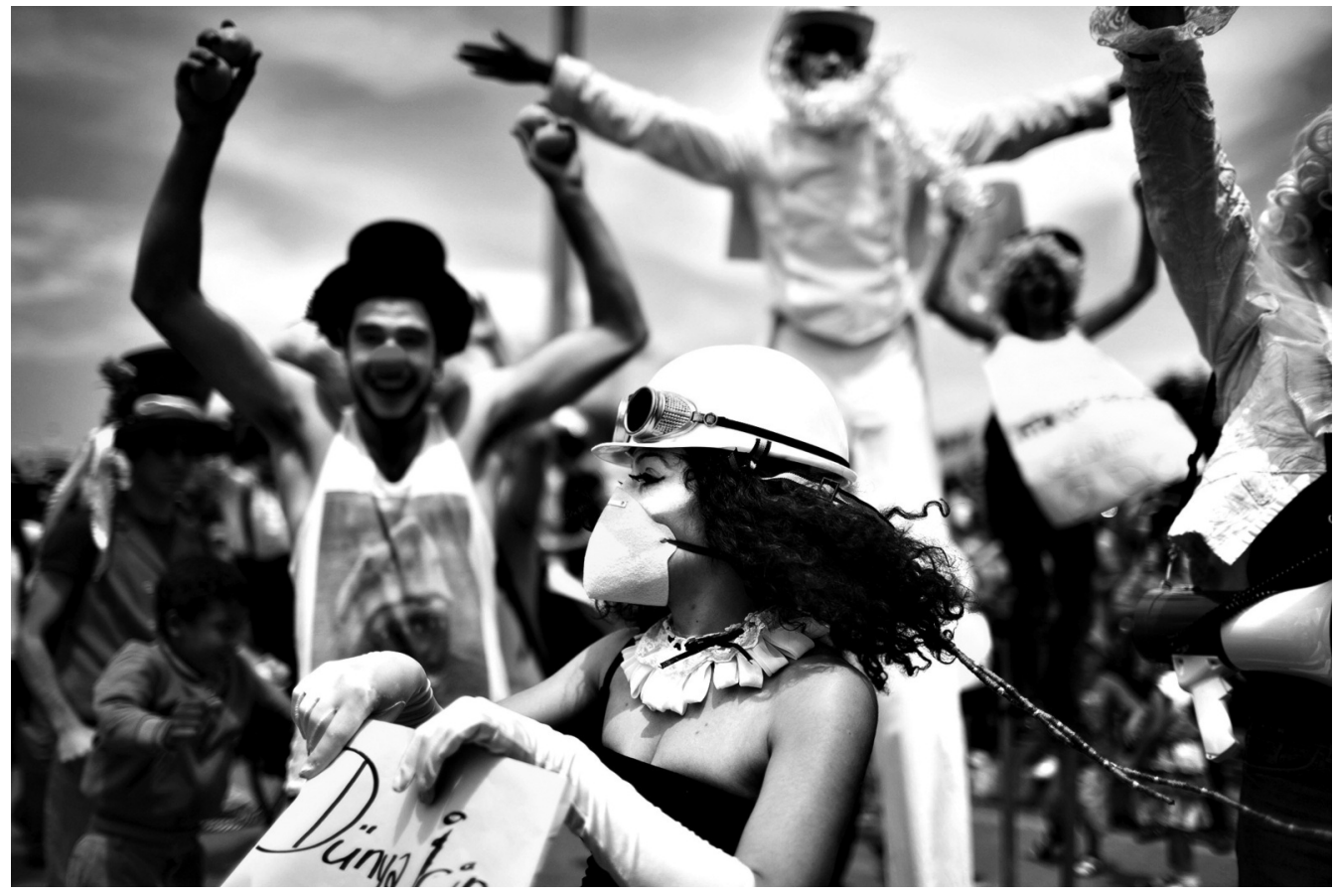

En kunstgruppe protesterer til støtte for Gezi-parken.

decentralisering. ${ }^{2}$ De nye ideologiske formationer betyder dog ikke, at en endelig strategi for et nyt politisk projekt på venstrefløjen er nær. Denne artikels udgangspunkt er således at åbne op for en ny samtidshistorisk refleksion over venstrefløjen og den liberale ideologi i det moderne Tyrkiet foruden at skildre, hvordan Gezi-protesterne markerer en situation, hvorfra udviklingen af politik fremover kan udfolde sig. Argumentet lyder derfor ikke, at et nyt liberalt venstrefløjsprojekt er skabt i Tyrkiet, men at den ideologiske konstellation mellem liberalismens og socialismens tankesæt i højere grad end før synes attraktiv for politiske aktivister på den nye venstrefløj.

I dette kapitel forstås venstrefløjen grundlæggende som en politisk tendens, med en bred tilslutning til marxismen, socialismen og senere tendenser hos den nye venstrefløj, imens den liberale ideologi er tæt knyttet til identitetsskabende politik og kosmopolitisme. ${ }^{3}$ Da liberalismen ofte inkorporer økonomiske aspekter, bruger jeg betegnelsen den liberale ideologi eller liberale identitet til at fremhæve det rettighedsbaseret fokus, som liberalismen også indeholder. For at forstå den udvikling, begge ideologier i Tyrkiet har været igennem, må dette kapitel indledningsvis tag et kortere historisk tilbageblik.

\section{Kemalisme, radikalisme og stagnering}

I 1960 blev Tyrkiets første militærkup en realitet efter, at militæret bl.a. i samarbejde med grupperinger både på venstre- og højrefløjen fjernede den folkevalgte statsminister Adnan Menderes og året efter lod ham hænge. Menderes var i løbet af 1950'erne blevet upopulær blandt begge de politiske yderfløje og dele af den bureaukratiske elite, som anklagede ham for at være i lommen på USA, 


\section{MATHIAS FINDALEN BICKERSTETH}

efter at Tyrkiet var blevet NATO-medlem i $1952 .{ }^{4}$ Ligeledes bekymrede man sig over den omfattende stats privatisering, Menderes havde fået gennemført, ligesom hans religiøse værdier kolliderede med den stringente sekulære dagsorden, staten forsvarede. Militærkuppet var derfor i overvejende grad et forsøg på at forsvare statens enhed og sekulære karakter, samtidig med at afskaffelsen af Menderes for alvor medførte en tiltro til, at studenterbevægelserne og militæret i samarbejde var $\mathrm{i}$ stand til at ændre den politiske situation. ${ }^{5}$ Venstrefløjen og militæret havde på det tidspunkt $i$ et vis omfang den kemalistiske ideologi til fælles. Kemalismen ideologiske univers var især kommet på landkortet efter dannelsen af Tyrkiet i 1923 og offentliggørelsen af den første politiske forfatning i 1924. I den periode var det Atatürks parti cHP (Cumhuriyet Halk Partisi, Det republikanske folkeparti), som dominerede det politiske landskab. Det var især statsbureaukrater og militæreliten, der lod sig inspirere af Atatürks tanker, også efter Atatürks død i 1938 hvor tilhængere udviklede det semantiske indhold i kemalismens seks politiske søjler: republikanisme, sekularisme, populisme, etatisme, nationalisme, revolutionisme. ${ }^{6}$ Disse seks søjler omkransede kemalismens grundfilosofi, som byggede på at holde den 700 årige islam-osmanniske tradition $\mathrm{i}$ ave, hvilket inkluderede adskillelsen af religion fra staten. Det, som på tyrkisk og hentet fra det franske ord laicisme kaldes laiklik, henviser til statens kontrol af religion, så den holdes uden for statslige anliggender.

Da kemalismen udviklede sig sideløbende med den tyrkiske statsdannelse, er den ofte blevet anset som i ledtog med nationalisme, fordi den sammen med både regeringen, retsvæsenet og uddannelsessystemet blev den primære forsvarer af den tyrkiske identitet. ${ }^{7} \mathrm{Da}$
Atatürk aldrig selv udarbejdede en færdig doktrin for sine politiske ideer, har der hersket en magtkamp over, hvem der havde patent på kemalismen som ideologi. Kemalismen har derfor både haft stor indflydelse på venstre- og højrefløjen i Tyrkiet ud fra strategien om at homogenisere landet, der ellers under Osmanneriget havde været kendetegnet ved et miks af forskellige kulturer og etniciteter. ${ }^{8}$

I kølvandet på militærkuppet i 1960 blev der udformet en ny forfatning, som blev anset for at være væsentlig mere liberal og åbensindet, da den for alvor gjorde op med et-parti systemet fra 1923-1950 ved at tillade en mere plural foreningsaktivitet. 9 Dette fik i den grad

Der er politisk opbakning til at forsvare liberale verdier som pluralisme, rettigheder, selvbestemmelse og tolerance.

politiske foreninger og institutioner til at blomstre, og en række beslægtede venstrefløjsbevægelser begyndte at vinde frem. Især universitetsstuderende implementerede mange teorier og metoder hentet fra den socialisme, der i samme periode vandt frem i Europa og Latinamerika. Massevis af demonstrationer, og protester blev gennemført og bevægelserne steg i medlemsantal. Studenterledere tog til palæstinensiske guerillalejre i Libanon, og fagforeninger blev mere radikale i deres krav og militante i deres praksis. I denne periode vandt kurdiske grupperinger ligeledes frem - blandt andet inspireret af 1968-opgøret i Europa og de globale protester mod Vietnamkrigen. ${ }^{10}$

Forståelsen af væbnet kamp som en afgørende faktor for samfundsomvæltning eskalerede yderligere ind i begyndelsen af 1970'erne, hvor en stigende radikalisme og 
militarisme etablerede sig på venstre- og højrefløjen. ${ }^{11}$ I den periode tiltrak ungdommens guerillabevægelser med de revolutionære Mahir Çayan og Deniz Gezmis i spidsen mange studerende på venstrefløjen. De brugte kidnapninger og terroraktioner til at fremme politiske mål og tog aktivt del i militære kampe mod højrenationalister.

Den manglende evne fra regeringen til at nedkæmpe de militaristiske grupperinger medførte det tredje militærkup den 12. september i 1980. 1970'ernes mange politiske mord og sammenstød havde skabt et usikkert politisk klima, og derfor bar dette militærkup modsat tidligere præg af et fast greb om politiske aktivister, som blev fængslet, og politiske partier, foreninger og forsamlinger blev lukket ned. Dette gik især ud over venstrefløjen, som blev splittet $i$ atomer. ${ }^{12}$

Hvor 1960'erne i faglitteraturen og historiebøgerne kædes sammen med masseaktioner, protester og strejker, beskrives 1970'erne i overvejende grad med radikalisme og militarisme. ${ }^{13}$ Ligesom flere anser militærkuppet i 1980 for at være det endegyldige punktum for venstrefløjens rolle i tyrkisk politik, hvor den igennem massiv statsundertrykkelse fragmenteredes og derfor manglede ideologisk retning. ${ }^{14}$ Denne udvikling har haft en markant påvirkning på forskningen af den tyrkiske venstrefløj. Her har der helt frem til i dag i overvejende grad hersket konsensus om, at venstrefløjen aldrig rigtig formåede at etablere en bæredygtig politik og derfor siden 1970'erne efterlod sig selv i en omfattende krise, der stadig gælder i dag. ${ }^{15}$

1980'erne blev også kendetegnet ved, at den revolutionære ånd fra 1960'erne var gemt væk . Socialismen blev stort set udvisket fra det politiske landskab, og den marxistiske ideologis indflydelse blev formindsket især gennem hærens opløsning af venstrefløjspartier - ligesom 1950'erne havde med-virket til en massiv urbanisering af mange konservative arbejdere, som nu i 1980'erne overtog kampen for social retfærdighed fra den ødelagte venstrefløj. ${ }^{16}$ Venstrefløjen fik derfor sværere ved at række ud til arbejderklassen. Den var ligeledes nødsaget til at implementere de demokratiske normer, der var dukket op med murens fald i 1989 samt den globale udvikling, som havde åbnet op for et bredere identitetspolitisk fokus modsat den klassebevidsthed og de økonomiske kampe, man havde fokuseret på tidligere. Dele af venstrefløjen begyndte således at definere sin ideologiske platform $i$ forhold til socialdemokratismen, mens den gamle venstrefløj trak sig i baggrunden, og arbejderbevægelsens magt blev reduceret. ${ }^{17}$

\section{Den liberalistiske trussel}

Selvom venstrefløjsideologierne socialisme og marxisme især siden 1980'erne har haft svært ved at etablere sig i det politiske landskab i Tyrkiet, har aspekter indenfor liberalismen såsom frihedsrettigheder til at dyrke individuelle identiteter $\mathrm{i}$ lige så høj grad været mødt af politiske forhindringer. En af de væsentligste grunde til det er kemalismen og dens stærke indflydelse både på tyrkisk samfund og kultur, hvor Tyrkiet skulle kun være én klasse; det tyrkiske folk. Kemalismen frygtede derfor grundlæggende den grænseløse kosmopolitiske tilgang indlejret i liberalisme, som medførte, at den ikke var tilknyttet en fast race, politik og etnicitet og blev derfor anset som en trussel mod den tyrkiske nationalidentitet. ${ }^{18}$

Trods liberalismen så småt begyndte at udspille sig i det tyrkiske samfund i 1950'erne gennem den stigende urbanisering og industrialisering under Menderes, vandt en 


\section{MATHIAS FINDALEN BICKERSTETH}

økonomisk liberaliseringsbølge med inspiration fra det globale marked først frem i Tyrkiet i 1980'erne under den tyrkiske premierminister Turgut Özal. Dette inspirerede nye politiske positioner blandt liberale intellektuelle, og argumenterne gik i endnu højere grad for mere stats-decentralisering, udvidelse af civilsamfundet og beskyttelsen af det enkelte individ. ${ }^{19}$ Samtidig fremmanede de liberale budskabet om, at demokrati kun kunne fungere ved hjælp fra den frie markedsøkonomi, hvilket påkaldte et opgør mod det tyrkiske statsbureaukrati. Det mindretal af venstrefløjs-aktører, som stadig var aktive, havde på trods af deres modstand mod den liberale markedsøkonomi en række rettighedsidealer til fælles med den liberale identitet. Denne periode viste tegn på, at det, der i Europa blev betegnet for the new left, også var begyndt at spire i Tyrkiet.

New left-traditionen var kendetegnet ved at italesatte en anden humanisme, som i højere grad end fortidens universelle abstraktioner som "partiet» eller "verdensrevolutionen» placerede det enkelte menneske i centrum for den socialistiske ideologi. The new left var ny $i$ den forstand, at den flyttede fokus fra arbejderkampen som det centrale til et identitetsspørgsmål og kampen for frigørelse igennem studenterbevægelser, kvindebevægelser og borgerinitiativer etc. Det er især på det spørgsmål, at new left både adskilte sig fra den gamle venstrefløj og socialdemokratismen, fordi hverken arbejderklassen eller fagforeninger blev anset som en forudsætning for new lefts politiske ageren. ${ }^{20}$

Efter murens fald i 1989 begyndte new left at indtage en løsere struktur. Her blev bevægelsen i stedet en del af et bredere landskab af sociale bevægelser, hvor liberale budskaber begyndte at blive attraktive. Det gjaldt også i 199o'erne i Tyrkiet, hvor identitetspolitiske opråb og miljøorienterede bevægelser dukkede frem i civilsamfundet, som på dette tidspunkt var begyndt at blomstre i de urbane miljøer. Især miljøbevægelserne var inspireret af internationale new left-tendenser, mens menneskerettighedsbevægelsen mere tog udgangspunkt i den nationale kontekst, hvor alt fra homoseksuelle til kurdere og armenere oplevede en voldsom stigmatisering. Dette medførte, at minoritetsrettigheder for første gang for alvor fik rodfæste i den offentlige debat. Selvom det også medførte, at flere venstreliberale rettighedsorienteret bevægelser begyndte at vinde frem, var en reel politisk indflydelse fraværende, idet den stringente statskontrol stadig dominerede. Den kontrol forhindrede yderligere mobilisering blandt liberale og socialistiske aktivister og intellektuelle, som derfor mest opererede igennem mindre politiske magasiner. ${ }^{21}$

Den mest markante politiske bølge i Tyrkiet, som $i$ et vis omfang relateres til liberale budskaber, kom, da det nuværende AKP vandt valget i 2002. I begyndelsen af regeringsperioden reformerede AKP lovgivningen ud fra liberale ideer; flere rettigheder til kurdere, decentralisering af militærets og retsvæsenets magt og genoptagelse af Eu-optagelsesproces. Det mobiliserede i starten politiske kredse med tilknytning både til både liberale og socialistiske budskaber. Men lige så stille begyndte liberalismens økonomiske sider at skabe problemer for venstrefløjen, som var modstandere af AKPS økonomiske ideer om kontinuerlig kapitalprofit, masse-produktion og stigende vækst. Dette besværliggjorde ligeledes en bæredygtig forening mellem imellem et liberalt og socialistisk vokabular. ${ }^{22}$

\section{Identitetspolitikkens markante fremkomst}

Ifølge flere venstrefløjsaktivister blev det sålunde først i mødet mellem forskellige 
grupperinger og en række individuelle politiske krav og opråb under Gezi-protesterne sommeren 2013, at muligheden for at etablere liberale og socialistiske bæredygtige fællesskaber blev skabt. Der er sågar påbegyndt en ny liberal venstrefløjstrend, som journalist Tim Arango i sin reportage i New York Times også har bemærket. Her argumenteres for, at de konstante massebyggerier samt statens vold i løbet af protesterne for mange liberale blev dråben, der fik bærret til at flyde over. Ceziprotesterne beviste dermed, at liberale læner sig mere op af venstrefløjsstemmer som miljøaktivister og feminister end AKPS neoliberale byggeprojekter og regeringsautoritære tendenser. ${ }^{23}$ Ligeså vel som den nye venstrefløj anser Cezi-protesterne som et klart udtryk for, at de har rekonstrueret sig selv ved at åbne op for end mere liberal tænkning. Den nye venstrefløj er 'ny', fordi den har indset sine tidligere politiske fejl og har fundet den rette socialisme, som formanden Ahmet Saymadi for det forholdsvis nye lille venstrefløjs parti sYKP (Sosyalist Yeniden Kurulus Partisi, Socialismens rekonstruktion og frihedspartiet) pointerede:

Some years ago the LCBT and feminist movement started to develop their ideological platform while the socialist movement was stagnated. Cezi changed that. ${ }^{24}$

Disse identitetspolitiske former blev under Cezi-protesterne beviset på, at begreber knyttet til den liberale identitet som fremdrift, frihed, forskellighed, individualitet, ytringsfrihed, og decentralisering placeres i forgrunden af det politiske samfund i større grad end tidligere. Netop det er ifølge Ahmet med til at konstruere en relation mellem både en liberal tænkning og socialistiske ideer om fx sammenhold og solidaritet - det flere af demonstranterne kaldte: "The fight in solidarity for more individuals rights." Her præsenteres en ideologisk sammensætning, som ifølge Ahmet afspejler en stigende tendens blandt flere nye venstrefløjsbevægelser til ikke længere at se så stringent på tidligere tiders makroideologier (socialisme, konservatisme og liberalisme). Han bemærker blandt andet, at hans eget parti de senere år har ladet sig inspirere af liberale elementer ved hjælp af en identitetspolitisk tilgang. Anskuelsen er forholdsvis ny, idet både etnicitet, køn og seksualitet ofte har været fjern fra venstrefløjen, der har set emnerne som en trussel mod den tyrkiske identitet.

The idea is both to embrace the Kurdish, The LCBT and the feminist movement without excluding any one of them. We are in the making of reconstructing socialism. 25

Denne politiske ændring har medført, at flere af de nye venstrefløjspartier har opsat kvoter, der giver plads til homoseksuelle og kvinder i de respektive partier. Det nystartede venstrefløjsparti HDP (Halklarin Demokrat Partisi, Folkenes demokratiske parti), som blandt andet har tilknytning til det folkevalgte og parlamentariske kurdiske parti вDP (Barıs ve Demokrasi Partisi, Freds- og demokrati-partiet), har eksempelvis allokeret 50 procent af sin ledelse til kvinder og 10 procent til LGBT-personer. ${ }^{26} \mathrm{Et}$ politisk træk som ikke umiddelbart har været en ulempe: HDPs kandidat Selahattin Demitas fik med opråb om medborgerskab, bæredygtig $ø$ kologi og minoritetsrettigheder ved seneste præsidentvalget i august 2014 næsten 10 procent af stemmerne, hvilket er en stigning fra de cirka 5 procent HDP fik et halvt år tidligere ved lokalvalget, og påpeger eksistensen af en efterspørgsel efter en identitetspolitisk venstrefløj.

Selvom identitetspolitik i høj grad knytter sig til liberale budskaber, er det ikke en ideologi i sig selv. Som en aktivist fra Cezi- 


\section{MATHIAS FINDALEN BICKERSTETH}

protest fællesskabet Taksim solidarity platform, der ønskede anonymitet, pointerer:

The strong focus on identity politics should more be seen as a moderator between the meeting of different identities related to the liberal left. This meeting of different individual political massages produce new thinking.

Dette skildrer et markant brud med den enhedstankegang, som kemalismen før har repræsenteret på venstrefløjen, hvilket ligeledes tydeliggør et ideologiske skel mellem den gamle og nye venstrefløj i Tyrkiet. Hvor størstedelen af venstrefløjsbevægelser tidligere var i tæt alliance med militæret og statslige institutioner, er nyere venstrefløjsbevægelser i højere grad kendetegnet ved at artikulere en afstand til bureaukratiske institutioner knyttet til den kemalistiske ideologi. Ahmet påpeger, at forholdet til kemalismen er en af de tydeligste væsensforskelle på den gamle og den nye venstrefløj. Den nye venstrefløj ser i højere grad Atatürk som et kulturelt symbol, imens flere ældre venstrefløjsbevægelser stadig betragter ham som en politisk motiverende faktor.

Ahmet kritiserer bl.a. kemalister for at holde fast i et narrativ, der ikke udvikler sig men besidder stereotype ideer om den tyrkiske befolkning. I den forbindelse bruger han kemalismen som forklaring på, hvorfor hans parti artikulerer sig som en rekonstruktion af venstrefløjen. Førhen medførte den gamle venstrefløjs tætte relation til kemalismen, at man ikke formåede at have en tydelig strategi for, om socialismen skulle skabes top-down eller bottom up. Om det var kemalismens bureaukrati eller folket i sig selv, der indeholdt revolutionær potentiale, var derfor uklart.

\section{Miljøbevægelser og de liberale tendenser}

Den markante fremkomst af identitetspolitik er også mulig at identificere hos en række miljøbevægelser, som var nogle af de første til at tage del i Cezi-protesterne, fordi protesterne i starten netop centrerede sig om en række urbane miljøproblemstillinger knyttet til AKPS neoliberale økonomiske byggeboom. Dette viser samtidig, at miljøbevægelser har mere resonans i dag end tidligere, fordi de $ø$ kologiske problemer i samfundet er blevet væsentlig tydeligere de senere år. To af de miljøbevægelser er Müstereklerimiz og YSGP (Yesiller ve Sol Gelecek Partisi, De grønne og fremtidens venstreparti).

Müstereklerimiz betyder «our commons» og bemærkede sig under Gezi-protesterne igennem flere politiske initiativer, hvor forskellige holdninger og ideer blev delt i fora med ordstyrere og referenter. Der blev ligeledes udviklet politiske manifester og praktiske tiltag med det formål at forbedre solidariteten og forholdene for befolkningen. Som det fremgår af bevægelsens hjemmeside, er deres hovedformål at forhindre omfattende urbane omvæltninger, der har medført, at flere af Istanbuls lokale forstæder er blevet revet ned til fordel for tusindvis af skyskrabere, storcentre og motorvej. ${ }^{27}$

Den 30-årige filminstruktør Imre, som tidligere har været involveret i netværket, fortalte, at Müstereklerimiz generelt er kendetegnet ved offentligt ikke at besidde medlemmer eller operere uden et magtcenter. ${ }^{28}$ Bevægelsens formål er at repræsentere alle former for identiteter, samtidig med at de kæmper for flere rettigheder til underklassen i et samfund, der i stigende grad fremmedgøres af AKPS neoliberale univers. De ser derfor sig selv som en del af et større fællesskab, der ønsker at bringe fokus på de enorme urbane problemer i Tyrkiet.

The capitalist system can no longer hide the consequences of the crisis it is crippling into. Fast-paced ecological 
destruction and global economic crisis mean the same thing for all the poor and the oppressed throughout the world: disaster. ${ }^{29}$

Det bemærkelsesværdige er, at det netop er igennem Müsterekleremiz urbane miljøfokus, at der tydeligt kan identificeres en kapitalismekritik, som fremviser en kombineret venstrefløj og liberal tilgang. Igennem deres politik synliggør de menneskets emancipation, klassekamp og forholdet mellem kapital og arbejde - altså kapitalismens modsætningsforhold, samtidig med at de argumenterer for plurale rettigheder.

Denne politiske tilgang blev også bekræftet af Ufuk Uras tidligere parlamentariker og medlem af den anden miljøbevægelse YSGP "Cezi showed that there exist a strong coalition between ecological issues, liberal rights ideas and a solidarity spirit.»30 Den endelig mulighed for et ideologisk samarbejde har ifølge Ufuk medført, at et klassisk socialismebegreb som lighed nu også kan knyttes til det, han kalder liberale budskaber: inklusion af alle identiteter, indskrænkning af statens magt, det almene vel og fremdrift af samfundets kulturelle forståelse. ${ }^{31}$

\section{De nye ideologiske formationer}

Hvad der for den nye venstrefløj umiddelbart fremstår interessant ved liberale politiske begreber er, at de indeholder en temporalitet, som bryder med fastlåse positioner. En temporalitet som ikke på samme måde har eksisteret før hos den tyrkiske venstrefløj, og som er kendetegnet ved et fravær af grænser og ved at indeholde en uafsluttethed, som går mod den kemalistiske enhedstankegang. Som antropolog Jenny White påpeger: «The willingness to $\mathrm{mix}$ is central to liberal identity. .132 Denne tendens står i stærk kontrast til klassiske socialistiske teorier om det universelle parti, verdensrevolutionen og social selvrealisering. Gezi-protesterne var i den sammenhæng med til at frembringe en liberal orientering. Som Imre pointerede under Gezi-protesterne: "This is my own protest against a system, I, in all it's aspects do not

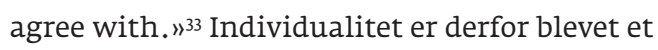
kernebegreb i det nye venstrefløjsprojekt, som gør politiske aktører i stand til at sammenflette ideologier ud fra det, der passer bedst ind i den hverdag, de indoptager og tager del i. Venstrefløjen skal altså forstås ud fra nye bedømmelsesparametre.

Teknologien spiller her en rolle, frembrusede Imre. «Social media gives the young generation I'm a part of a possibility to create an autonomous room, where the state bureaucracy is confronted with new concepts and projects. 134 Idet sociale medier giver plads til individuel ideologiproduktion, giver det også plads til mange former for identitetsdannelser, hvilket er med til at fremdrive liberale budskaber, som vægter en bevægelse fra det stringente hen mod det mangfoldige. De venstrefløjsaktører, der tog del i Gezi-protesterne, er derfor også kendetegnet ved hurtigt at analysere det politiske rum, skifte taktik og indoptage nye slogans. Denne konstante positionsforhandling gør en fleksibel tilgang til ideologier mere tilgængelig modsat den tidligere partisoldat med kun ét sæt slogans og taktik.35 Omvendt kan det fremhæves, at flere af de interviewede aktivisters politiske budskaber og opråb måske kommer til at lide af, at deres ideer og tænkning stadig ikke har fundet rodfæste. Derfor kan de mange ideologikombinationer og liberalismens frihedsparadigme være med til at sløre billedet i en fase, hvor der skal skabes enighed og samling om nye mål og ny en retning på samfundet. Ligesom det for mange af de politiske aktivister, der deltog i 


\section{MATHIAS FINDALEN BICKERSTETH}

protesterne, var første gang de involverede sig åbenlyst i politisk aktivitet. Dette forklarer tendensen til at forstå protesterne individuelt og liberalt, siden mange unge i Tyrkiet i dag ikke er vant til politisk partimobilisering.

Imidlertid har den liberale tendens ikke fundet $\sin$ definitive plads hos nye venstrefløjsprotestbevægelser i Tyrkiet, idet liberalismen som ofte postuleret ikke har fejet alle andre ideologier til side. Opgøret i Tyrkiet viser således, at andre ideologier stadig lever i bedste velgående, bare ud fra forskellige parametre. Selvom den kemalistiske ideologi vækker mindre interesse hos store dele af den unge generation efter Gezi-begivenheden, spiller den stadig en stor politisk rolle hos eksempelvis nationalistiske bevægelser i landet. ${ }^{36}$ Ligeledes vandt bl.a. en anarkistiskekemalistiske bevægelse, som blander anarkistisk politik med en kultdyrkelse af Tyrkiets stifter Mustafa Kemal Atatürk, frem under Gezi-protesterne.

Denne ideologiudvikling, som dette kapitel har identificeret, handler derfor mere om, at den måde, hvorpå forskellige politiske diskurser har forsøgt at tage patent på forståelsen af liberalismen, har givet flere muligheder for at begrebsliggøre og undersøge ideologier. Den stigende individualisering har skabt en ideologisk fleksibilitet. ${ }^{37}$ Dette blev tydeligt hos flere af de aktivister, jeg mødte i Istanbul og Ankara, hvoraf størstedelen hentydede til, at stigende krav om rettigheder og solidaritet ikke behøver at være i konflikt med det, de betegner som liberale ideer om økonomisk fremgang og produktivitet. De er kun imod økonomisk kapitalisme, når den privatiserer og fremmedgør arbejderen ved at fjerne dem fra sin arbejdsplads og bopæl, som regeringsmagten har gjort de senere år. Som Marc, aktivist fra miljøpartiet YSGP bemærkede. "We recognize the need for economic development to expand civil rights, but we must find a way to circumvent the neoliberal development. .138

Adspurgt direkte, om venstrefløjsaktivisterne også ser sig selv som liberale, påpeger de fleste, at der er politisk opbakning til at forsvare liberale værdier som pluralisme, rettigheder, selvbestemmelse og tolerance, samtidig med at det neoliberale, centreret omkring økonomisk markedstænkning og arbejderfremmedgørelse bliver afvist. Flere af aktivisterne tager altså samtidig afstand fra liberaliseringen, når den knyttes til globaliseringen. Ufuk fra YSGP forklarede det således. "The liberal connection to globalism is a capitalistic threat towards the working people. ${ }^{39}$ Lige præcis det anti-globale element viser, at de nye bevægelser på trods af deres afstandstagen til den gamle venstrefløj stadig har en historisk rod i venstrefløjens antiimperialisme og antikapitalistiske ånd.

Den globale kritik er dog ikke et argument for nationalisme, men en anerkendelse af, at de liberale rettigheder også kan gælde indenfor nationalstaten. Ligeledes behøver det nye venstrefløjsprojekts sammenkobling med liberale begreber ikke at betyde et bifald af et socialdemokratisk projekt. Tværtimod tyder meget på, at den nye venstrefløj adskiller sig fra denne tradition ved at nægte at gå på kompromis med neo-liberale eller globale udviklingstendenser, som klassiske socialdemokratiske partier ofte er blevet kendt for at adressere..$^{\circ 0}$ Snarere kan en analyse være, at udviskningen af den historiske dikotomi mellem liberalisme og socialisme har fremført en afessentialisering af et fast politisk indhold, og derfor har begge ideologier en tendens til at afkoble sig statussen som overordnet makroideologier. ${ }^{41}$

Som Gezi-protesterne har vist, sker udviklingen i højere grad på græsrodsniveau, 
hvor ideologier konfronteres af nye former for aktivisme og politiske tænkning. Denne situation er med til at skabe ideologiske formationer, der er i større grad end tidligere ikke har faste partiprogrammer som navigationsredskaber. ${ }^{42}$ Bedst eksemplificeret ved at størstedelen af de venstrefløjsbevægelser, jeg har stiftet bekendtskab med efter Gezi- protesterne, enten er i gang med at omskrive deres politiske ideer eller forme helt nye. Den ideologiske forhandling er fortsat konstant i gang!

\section{$\bullet$}

1 Eskinat, Dogan: "Gezi Park: Negotiating a new left identity. Insight Turkey, 15. Nr. 3, 2013, s. 45.

2 Alessandrini Anthony, Üstündag Nazan \& Yildiz Emrah (red): "Resistance everywhere: The Gezi protests and dissident visions of Turkey". JADMAG. Tadween publishing. 2013, s. 8.

3 McCullough, B. H: Political Ideologies. Oxford University Press. 2010, s. 130.

4 Öktem, Kerem: Angry Nation - Turkey since 1989. Fernwood publishing ltd. 2010, s. 48-50.

5 Mutlu, Ulus Özgür: The army and the radical left in Turkey. I.B.Tauris \& co. New York, 2012, s. 4.

6 Hanioglu, M, Sükrü (Kuru T. Ahmet \& Stepan C. Alfred) i: Democracy, Islam, Secularism in Turkey. Columbia University Press. New York, 2012, s. 33

7 White, Jenny: Muslim Nationalism and the New Turks. Princeton University press. 2012, s. 39

8 Samim, Ahmet ("Ahmet Samim» er pseudonymet til venstrefløjsaktivsten Murat Belge) i: Shick C. Irwin \& Tonak Ertugrul, Ahmet: "The left" i: Turkey in transition: new perspectives. Oxford University Press. Oxford. 1987, s. 169

9 ibid.

10 Marcuz, Aliza: Blood and Belief. New York University Press 2007, s. 50

11 Öktem, Kerem (2011). s, 48-50

12 Mutlu Ulus (2011), s. 5

13 Se: (Samim 1987, Mutlu Ulus 2011, Öktem 2011)

14 ibid.

15 Atlas, Duygu: "People's Democracy Party (HDP): A Breath of Fresh Air for the Turkish Opposition?" Tel Aviv notes 7, nr. 22, 2013, s. 2-4.

16 Öktem (2011). s, 41-42.

17 Gürpinar, Dogan: "The trajectory of left-liberalism in Turkey and it's nemesis: The great rupture in the Turkish left”. Insight Turkey, 14. Nr. 1, 2012, s. 147-168.

18 ibid.

19 ibid.

20 Jayati Gosh: "The Emerging Left in the 'Emerging' World". MR, Zine. 26.06.2012 http://mrzine.monthlyreview.org/ 2012/ghosh260612. html

21 Cürpinar, Dogan (2012), s. 147-168

22 Tim Arango: "Turkish Liberals Turn their backs on Erdogan", i New York Times (International Edition), 19.6.2013 http://www.nytimes.com/2013/o6/20/world/ europe/turkish-liberals-turn-their-backs-on-erdogan. $\mathrm{html}$ ?pagewanted=all\&_r=1\&

23 ibid.

24 Interview med formanden for venstrefløjspartiet SYKP (Sosyalist Yeniden Kurulus Partisi, Socialismens rekonstruktion og frihedspartiet) Ahmet Saymadi i Istanbul den 01-10.13. Information også hentet fra partiets website: http://www.sosyalistyenidenkurulus.org/

25 ibid.

26 Selin Çaglayan: "New People's Democratic Party (HDP) in Turkey hopes to unite socialists and Kurdish opposition". Organized rage. 11.11 2013. http://www. organizedrage. $\mathrm{com} / 2013 / 11 /$ new-peoples-democratic-party-hdp-in.html

27 Müstereklerimiz website: http://mustereklerimiz.org/ our-commons-who-why/

28 Interview m. Imre. Aktivist og filminstruktør i Istanbul den 02.10 .13

29 Müstereklerimiz website.

30 Interview $\mathrm{m}$. Ufuk Uras, medlem af miljøpartiet YSGP (Yesiller ve Sol Celecek Partisi, De grønne og fremtidspartiet) i Istanbul den 04.10.13.

31 ibid.

32 White, Jenny (2012), s. 114

33 Interview $\mathrm{m}$. Imre.

34 ibid.

35 Castells, Manuel: Networks of outrage and hope: social movements in the internet age. Cambridge University. 2012, s. 218-221.

36 White, Jenny (2012), s. 192.

37 Freeden, Michael: Ideology - a very short introduction. Oxford University press. 2003 , s. 95.

38 Interview med Marc. Medlem og økonomiansvarlig hos miljøpartiet YSCP (Yesiller ve Sol Gelecek Partisi, De grønne og fremtidspartiet) i Istanbul den 04.10.13.

39 Interview m. Ufuk Uras.

40 Mouffe, Chantel: Agonistics-thinking the world politically. Verso. London \& New York. 2013, s. 117-119.

41 Freeden i: Nevers Jeppe, Olsen Nicklas og Sylvest Casper i: "Liberalisme i en morfologisk optik" i: Liberalisme-Danske og internationale perspektiver. Syddansk universitetsforlag. Odense, 2013, s. 23-26.

42 Freeden, Michael (2003), s. 95. 